\title{
Korelasi Kadar Asam Urat dan High-Mobility Group Box 1 Serum dengan Keparahan Stenosis Arteri Koroner Pasien Sindrom Koroner Akut: Tinjauan Sistematis
}

\author{
Diding Heri Prasetyo ${ }^{1,2^{*}}$, Sally Aman Nasution ${ }^{1}$, Idrus Alwi ${ }^{1}$, Murdani Abdullah ${ }^{1}$ \\ 1.Departemen Ilmu Penyakit Dalam, Fakultas Kedokteran Universitas Indonesia/RSPUN \\ dr. Cipto Mangunkusumo, Jakarta \\ 2.Departemen Ilmu Penyakit Dalam, Fakultas Kedokteran Universitas Sebelas Maret/RS \\ dr. Moewardi, Surakarta
}

Korespondensi : didinghapeuns@gmail.com

\begin{abstract}
ABSTRAK
Pendahuluan: Sindrom koroner akut (SKA) adalah gangguan yang mengancam jiwa yang tetap menjadi sumber morbiditas dan mortalitas yang tinggi meskipun ada kemajuan dalam pengobatan. Asam urat dan high-mobility group box 1 (HMGB1) keduanya berperan penting dalam patofisiologi SKA, tetapi interaksi kooperatif antara keduanya dalam kejadian keparahan stenosis arteri koroner pada SKA, belum sepenuhnya jelas. Penelitian ini bertujuan untuk melakukan tinjauan sistematis maupun meta analisis untuk mensintesis hasil-hasil penelitian yang berbeda tersebut agar diperoleh data baru yang bersifat kuantitatif dan lebih akurat.

Metode: Protokol penelitian didaftarkan dengan PROSPERO (CRD42020210948) dan tinjauan sistematis mengikuti pedoman preferred reporting items for systematic reviews and meta-analyses (PRISMA), dengan menelusuri studi yang dipublikasikan dalam rentan waktu dari Januari 2010 hingga Mei 2020. Cochrane Library, Ebsco, Medline/PubMed, ProQuest dan Sience Direct adalah sumber dari studi yang dipublikasikan. Meta-analisis dilakukan untuk mensintesis korelasi antara kadar asam urat dan HMGB1 serum dan keparahan stenosis arteri koroner. Heterogenitas dinilai menggunakan $\mathrm{I}^{2}$, dan meta analisis menggunakan perangkat lunak Comprehensive Meta Analysis Version 3 (CMA3).

Hasil: Lima studi $(\mathrm{n}=601$ pasien) diidentifikasi didapatkan korelasi antara kadar asam urat serum dan skor Gensini ( $r=0,548 ; \mathrm{p}<0,001)$ pada pasien SKA. Sedangkan, korelasi antara kadar HMGB1 serum dan skor Gensini pada pasien SKA didapatkan satu studi $(\mathrm{n}=60$ pasien) dengan nilai $\mathrm{r}=0,588 ; \mathrm{p}<0,001$. Bias heterogenitas ditemukan dalam analisis, sedangkan bias publikasi tidak ditemukan.

Kesimpulan: Keparahan stenosis arteri koroner pada pasien dengan SKA berkorelasi positip dengan kadar asam urat dan HMGB1 serum.
\end{abstract}

Kata kunci: asam urat; HMGB1; sindrom koroner akut; skor Gensini.

ABSTRACT

Introduction: Acute coronary syndrome (ACS) is a life-threatening disorder that has high morbidity and mortality despite advances in treatment. Both Uric acid dan high-mobility group box 1 (HMGB1) plays an important role in ACS pathophysiology, while the correlation between them in the severity of coronary stenosis in ACS is not completely clear. This study aims to conduct a systematic review and meta-analysis to synthesize the different research results in order to obtain new data that is quantitative and more accurate.

Methods: The research protocol has been registered with PROSPERO (CRD42020210948). The systematic review was done by following PRISMA guideline. Sources of the database were collected from Cochrane Library, Ebsco, Medline / PubMed, ProQuest, and Science Direct. The articles were published from January 2010 to May 2020. Meta-analysis was 
performed to synthesize a correlation between serum uric acid and HMGB1 levels and severity of coronary artery stenosis. Heterogeneity was assessed using $I^{2}$, and meta-analysis was done using Comprehensive Meta-Analysis Version 3 (CMA3) software.

Results: Five studies ( $n=601$ patients) identified a correlation between serum uric acid levels and Gensini score $(r=0.548 ; p<0.001)$ in ACS patients. Meanwhile, the correlation between serum HMGB1 levels and Gensini score in ACS patients was found in one study ( $n=$ 60 patients) with $r=0.588 ; p<0.001$. Heterogenity bias was found in the analysis, whereas publication bias did not found.

Conclusion. The severity of coronary artery stenosis in patients with ACS was positively correlated with serum uric acid and HMGB1 levels.

Keywords: acute coronary syndrome; HMGB1; Uric Acid; Gensini score.

\section{PENDAHULUAN}

Penyakit kardiovaskuler merupakan penyebab utama kematian di seluruh dunia. $(\mathrm{WHO})^{1}$. Sindrom koroner akut (SKA) menjadi penyebab utama kematian dan kecacatan di wilayah Asia-Pasifik, yang menyumbang sekitar setengah dari beban global, dengan mortalitas di rumah sakit yang biasanya melebihi $5 \%{ }^{2}$.

Sindrom koroner akut merupakan sindrom klinis dengan patogenesis kompleks multifaktor, melibatkan respon inflamasi, kerusakan imunitas, dan aktivasi fungsi pembekuan darah yang akan menyebabkan pecahnya plak dan pembentukan trombus ${ }^{3}$. Pecahnya fibrosa dan erosi superfisial plak menyebabkan kerusakan jaringan, stres sel ataupun nekrosis yang akan mengaktivasi sekresi maupun ekspresi high-mobility group box 1 (HMGB1) secara berlebihan, selanjutnya HMGB1 berikatan dengan pattern recognition receptor (PRR)-nya untuk mengaktivasi kaskade pro-inflamasi, hal ini akan lebih memicu lagi aktivasi patofisiologi plak aterosklerotik ${ }^{4,5}$.

Peningkatan kadar asam urat serum sebagai prediktor independen risiko kardiovaskuler masih diperdebatkan. Beberapa bukti epidemiologis hubungan kausal tersebut masih kontroversial dengan penelitian yang mendukung $^{6,7}$ atau menolak ${ }^{8,9}$. Hubungan antara peningkatan kadar asam urat serum dan penyakit kardiovaskuler dianggap sebagai "epifenomen" dan bukan kausal. Namun, bukti terbaru menunjukkan adanya hubungan antara kerusakan endotel, penyakit arteri koroner, dan kadar asam urat pada pasien SKA $^{10}$. Hasil meta analisis membuktikan bahwa hiperurisemia secara bermakna meningkatkan mortalitas dan risiko major adverse cardiovascular events (MACE) dan tingkat keparahan pasien $\mathrm{SKA},{ }^{11}$ tetapi perannya dalam penyakit arteri koroner masih belum diketahui ${ }^{12}$. Kadar asam urat serum berkorelasi positip dengan skor Gensini maupun skor Syntax sebagai salah satu sistem penilaian angiografi yang paling umum digunakan untuk memperkirakan tingkat keparahan lesi aterosklerotik berdasarkan hasil angiogram ${ }^{13}$.

Beberapa penelitian telah meneliti hubungan hiperurisemia dengan keparahan lesi arteri koroner dibandingkan normourisemia pada pasien SKA dengan batasan nilai definisi hiperurisemia yang berbedabeda, sehingga hasilnya juga berbeda. Berbagai studi klinis menunjukkan bahwa HMGB1 dapat sebagai biomarker pada pasien penyakit jantung koroner baik selama fase akut dan fase akhir pada pasien pasca infark. Kadar HMGB1 secara signifikan meningkat dalam serum pasien SKA dibandingkan dengan subyek sehat. HMGB1 tidak hanya sebagai penanda kerusakan dan respons inflamasi tetapi berperan penting dalam 
meningkatkan disfungsi miokard ${ }^{5,14}$. Pada hewan coba kadar HMGB1 meningkat satu jam setelah reperfusi ${ }^{15}$.

Bagaimanapun korelasi asam urat dan HMGB1 dalam kejadian keparahan stenosis arteri koroner pada SKA, belum sepenuhnya jelas. Penelitian awal secara invitro dari Cai dkk, pemberian asam urat dosis tinggi (20 $\mathrm{mg} / \mathrm{dL}$ ) pada human umbilical vein endothelial cells (HUVECs) meningkatkan ekspresi HMGB1 dan menginduksi terjadinya disfungsi endote $l^{16}$. Belum adanya tinjauan sistematis tentang permasalahan tersebut, mendasari peneliti untuk mencoba mengungkapkan korelasi kadar asam urat dan HMGB1 serum dengan keparahan stenosis arteri koroner pasien SKA. Diharapkan hasilnya akan memberikan dasar teoritis untuk pemahaman yang lebih baik tentang pencegahan dan pengobatan SKA.

\section{METODE}

Protokol penelitian didaftarkan di PROSPERO (CRD42020210948) dan tinjauan sistematis mengikuti pedoman preferred reporting items for systematic reviews and meta-analyses (PRISMA). Penilaian kritis masing-masing studi menggunakan pedoman alat penilaian kritis untuk menilai kualitas studi cross-sectional (AXIS). Meta Analisis data menggunakan perangkat lunak Comprehensive Meta Analisis version 3 (CMA versi 3).

\section{Strategi Pencarian.}

Pencarian literatur dilakukan di Cochrane Library, Ebsco, Medline / PubMed, ProQuest dan Science Direct. Penelusuran jurnal dilakukan menggunakan kosa kata dan kata-kata (MesH dan kata kunci) untuk mendapatkan subjek penelitian. Pencarian dilakukan untuk studi yang diterbitkan hingga Mei 2020 dan terbatas pada studi bahasa Inggris yang diterbitkan setelah 2010. Batasan waktu dipilih untuk memberikan refleksi kebaharuan dari asam urat serum dan HMGB1 dalam keparahan stenosis arteri koroner pada pasien SKA. Studi tambahan diidentifikasi dengan mencari daftar referensi artikel dan mencari literatur abu-abu dengan 200 hit pertama di Google Cendekia setelah memasukkan kombinasi istilah pengindeksan. Penelusuran literatur dilakukan oleh Diding Heri Prasetyo dan Murdani Abdullah, apabila terjadi perbedaan persepsi maka akan dilakukan mediasi oleh Sally Aman Nasution dan Idrus Alwi.

\section{Seleksi studi.}

Sampel diambil berdasarkan pedoman PRISMA dengan ketentuan kriteria inklusi mencakup (i) PICO (Population : pasien SKA; Intervention : kadar asam urat dan HMGB1 serum; Comparator group: keparahan stenosis arteri koroner (Gensini score); dan Outcome: korelasi kadar asam urat dan HMGB1 serum dengan skor Gensini), (ii) Penelitiannya adalah penelitian kuantitatif, (iii) Literatur diteliti/dipublikasi dalam rentan waktu Januari 2010 hingga Mei 2020, dan (iv) ditulis dalam Bahasa Inggris. Serta kriteria eksklusi: (i) abstrak, potongan bab buku, laporan kasus, review buletin, disertasi atau tesis master maupun penelitian yang tidak lengkap.

\section{Ekstraksi Data dan Evaluasi Kualitas.}

Reviewer secara independen melakukan penyaringan judul dan abstrak, ekstraksi data dan risiko penilaian bias. Penilaian risiko bias pada penelitian ini menggunakan rank corelation dan regression method.

\section{Sintesis dan Analisis Data}

Analisis dilakukan dengan menggunakan perangkat lunak CMA versi 3 . Heterogenitas statistik dinilai menggunakan statistik $\mathrm{I}^{2}$, dan studi dianggap memiliki tingkat heterogenitas tinggi jika nilainya $>75 \%$. 


\section{HASIL}

\section{Korelasi Kadar Asam Urat Serum dengan Tingkat Keparahan Stenosis Arteri Koroner Pada Pasien SKA.}

Pencarian literatur, ulasan, dan alasan untuk pengecualian studi dijelaskan pada gambar 1.

Hasil tinjauan kritis dengan AXIS tool terhadap kelima studi menunjukkan kualitas pelaporan dan desain studi baik, selain itu tidak menunjukkan adanya bias awal pengumpulan data. Deskripsi studi yang disertakan dalam tinjauan sistematis dan meta analisis, secara lengkap disajikan pada tabel 1 . tersebut secara lengkap disajikan pada tabel 2 .

Analisis terhadap variasi antar penelitian ditujukan untuk menentukan apakah antar penelitian heterogen atau homogen. Variasi antar penelitian dikatakan heterogen apabila nilai $\mathrm{p}$ pada uji heterogenitas $<0,05$ atau nilai $\mathrm{I}^{2}>75 \%$. Untuk menguji hipotesis dalam studi meta analisis, setidaknya ada tiga proses analisis yaitu: (i) menentukan rata-rata efek terbobot; (ii) menentukan interval kepercayaan, dan (iii) menguji signifikansi. Ketiga analisis tersebut dikenal dengan summary effect. Dalam menghitung summary effect biasanya digunakan dua model analisis yaitu fixed-effect

Tabel 1. Deskripsi studi yang disertakan

\begin{tabular}{lcrrr}
\hline \multirow{2}{*}{ Studi } & \multirow{2}{*}{$\begin{array}{c}\text { Jumlah } \\
\text { subjek }\end{array}$} & \multicolumn{3}{c}{ Populasi SKA } \\
\cline { 3 - 5 } & 246 & $97(39,4 \%)$ & $94(38,2 \%)$ & $55(22,4 \%)$ \\
\hline Duran et al., 2011 & 100 & $46(46,0 \%)$ & $50(50,0 \%)$ & $4(4,0 \%)$ \\
Qureshi et al., 2013 & 82 & $47(57,3 \%)$ & $24(29,3 \%)$ & $11(13,4 \%)$ \\
Pramanik et al., 2015 & 93 & $34(36,5 \%)$ & $29(31,2 \%)$ & $30(32,3 \%)$ \\
Ma et al., 2016 & 80 & - & $48(60,0 \%)$ & $32(40,0 \%)$ \\
Gaubert et al., 2018 & & & NSTEMI & UAP \\
\end{tabular}

Keterangan: SKA : Sindrom Koroner Akut; STEMI: ST-Elevation Myocardial Infarction; NSTEMI: Non-ST-segment Elevation Myocardial Infarction; UAP: unstable angina pectoris

Berdasarkan hasil tinjauan sistematis dari kelima artikel, didapatkan adanya korelasi positip antara kadar asam urat serum dengan keparahan stenosis arteri koroner (skor Gensini) pada pasien SKA ${ }^{10,17-20}$. Hasil luaran lain dari tinjauan sistematis ini didapatkan bahwa hiperuresemia pada pasien SKA berhubungan dengan keparahan, luas lesi dan jumlah oklusi total arteri koroner dibandingkan normourisemia ${ }^{17-20}$. Hasil tinjauan sistematis didapatkan lima penelitian layak untuk dianalisis menggunakan program CMA3, untuk mendapatkan besarnya estimasi effect size korelasi kadar asam urat serum dengan skor Gensini. Total subjek penelitian yang dianalisis sebanyak 601 subyek. Karakteristik data dari masing-masing jurnal model dan random-effect model. Berdasarkan uji heterogenitas, menunjukkan bahwa variasi antar penelitian pada meta analisis penelitian ini adalah heterogen (bervariasi) dengan $\mathrm{I}^{2}$ sebesar 90,5\% dengan $\mathrm{p}<0,001$ (tabel 3). Penelitian ini dalam menghitung summary effect menggunakan random-effect model (tabel 2). 
Prasetyo et al., Korelasi Kadar Asam Urat dan High-Mobility Group Box 1 Serum dengan Keparahan Stenosis Arteri Koroner Pasien Sindrom Koroner Akut: Tinjauan Sistematis

Tabel 2. Karakteristik data korelasi kadar asam urat serum dengan skor Gensini

\begin{tabular}{lccccccc}
\hline Studi & $\begin{array}{c}\text { Sample } \\
\text { size }\end{array}$ & $\mathrm{r}$ & $95 \% \mathrm{CI}$ & $\mathrm{Z}$ & $\mathrm{p}$ & \multicolumn{2}{c}{ Bobot (\%) } \\
& 246 & 0,452 & $0,347-0,546$ & 7,595 & 0,000 & 41.47 & 21.31 \\
\hline Duran et al., 2011 & 80 & 0,738 & $0,619-0,824$ & 8,302 & 0,000 & 13.14 & 19.43 \\
Gaubert et al., 2018 & 93 & 0,760 & $0,658-0,835$ & 9,451 & 0,000 & 15.36 & 19.80 \\
Ma et al., 2016 & 82 & 0,418 & $0,221-0,582$ & 3,958 & 0,000 & 13.48 & 19.50 \\
Pramanik et al., 2015 & 100 & 0,215 & $0,019-0,394$ & 2,147 & 0,032 & 16.55 & 19.96 \\
Qureshi et al., 2013 & 601 & 0,519 & $0,458-0,576$ & 13,931 & $<0,001$ & 100.00 & 100.00 \\
Fixed effects & 601 & 0,548 & $0,328-0,711$ & 4,397 & $<0,001$ & 100.00 & 100.00 \\
Random effects & & & & & & & \\
\hline
\end{tabular}

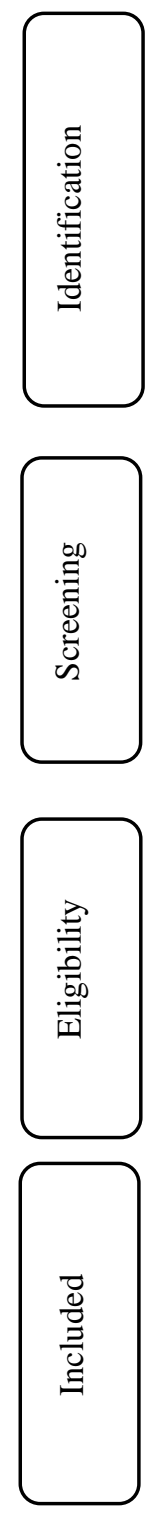

Records identified through

database searching $(n=1.216)$

- Cochrane Library $(n=45)$

- $\operatorname{EBSCO}(n=273)$

- Proquest $(n=51)$

- Medline / PubMed $(n=179)$

- SienceDirect $(n=668)$

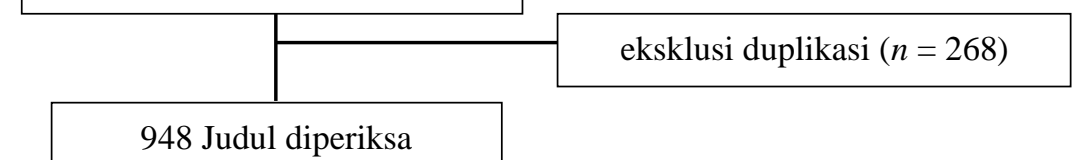

\section{Judul diperiksa}

870 Sitasi dikeluarkan setelah review judul

78 abstrak ditinjauan yang

berpotensi relevan diambil

full text tidak tersedia $(n=6)$

Full text layak di analisis $(n=72)$

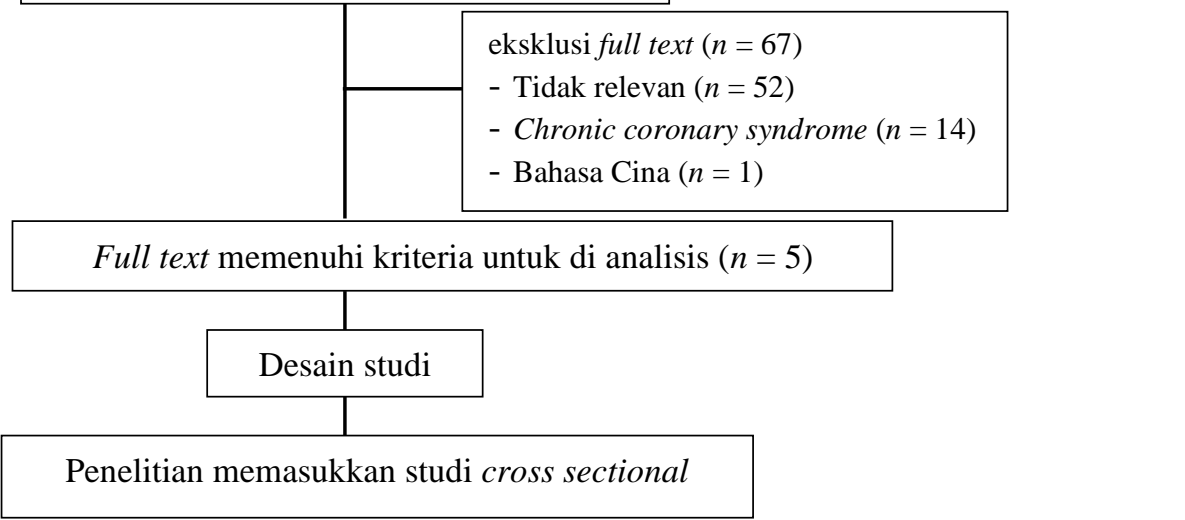

Gambar 1. Diagram alir korelasi kadar asam urat serum dengan tingkat keparahan stenosis 
Analisis terhadap variasi antar penelitian ditujukan untuk menentukan apakah antar penelitian heterogen atau homogen. Variasi antar penelitian dikatakan heterogen apabila nilai $\mathrm{p}$ pada uji heterogenitas $<0,05$ atau nilai $\mathrm{I}^{2}>75 \%$. Untuk menguji hipotesis dalam studi meta analisis, setidaknya ada tiga proses analisis yaitu: (i) menentukan rata-rata efek terbobot; (ii) menentukan interval kepercayaan, dan (iii) menguji signifikansi. Ketiga analisis tersebut dikenal dengan summary effect. Dalam menghitung summary effect biasanya digunakan dua model analisis yaitu fixed-effect model dan random-effect model. Berdasarkan uji heterogenitas, menunjukkan bahwa variasi antar penelitian pada meta analisis penelitian ini adalah heterogen (bervariasi) dengan $\mathrm{I}^{2}$ sebesar 90,5\% dengan $\mathrm{p}<0,001$ (tabel 3). Penelitian ini dalam meng-hitung summary effect menggunakan random-effect model (tabel 2 dan gambar 2).

Hasil forest plot (gambar 2) memperlihatkan korelasi masing-masing penelitian (kotak hitam) dengan interval kepercayaannya (garis horizontal) dan korelasi gabungan digambarkan dalam bentuk wajik (warna merah). Forest plot tersebut menunjukkan nilai $\mathrm{p}<0,05$, maka hipotesis nol di tolak. Dengan kata lain terdapat korelasi positip antara kadar asam urat serum dengan keparahan stenosis arteri koroner, dengan koefisien korelasi sebesar 0,548 yang dapat dikategorikan memiliki hubungan yang sedang dan berdasarkan uji signifikasi hasilnya menunjukkan nilai $\mathrm{p}<0,001$ yang berarti asosiasi kedua variabel adalah signifikan.

Tabel 3. Uji heterogenitas.

\begin{tabular}{lll}
\hline $\mathrm{Q}$ & $:$ & 42,1071 \\
$\mathrm{DF}$ & $:$ & 4 \\
Significance level & $:$ & $\mathrm{p}<0.0001$ \\
$\mathrm{I}^{2}$ (inconsistency) & $:$ & $90,50 \%$ \\
$95 \% \mathrm{CI}_{\text {for }}{ }^{2}$ & $:$ & 80,75 to 95,31 \\
\hline
\end{tabular}

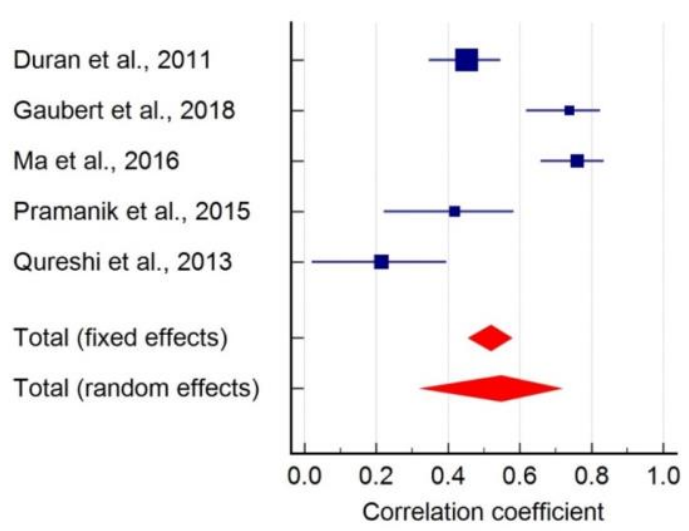

Gambar 2. Forest Plot korelasi asam urat dengan skor Gensini

\section{Penilaian Kualitas Studi.}

Bias publikasi. Studi yang dimasukkan dalam meta analisis ini kurang dari sepuluh studi. Penggunaan funnel plots untuk menilai bias publikasi hanya berdasarkan penilaian visual dan terkesan sangat subyektif, sehingga kekuatan tesnya dianggap terlalu rendah. Pada meta analisis ini menggunakan rank corelation dan regression method untuk menilai bias publikasi. Metode ini memberikan cara yang lebih objektif untuk mengidentifikasi adanya bias publikasi daripada funnel plots yang sangat subyektif. Hasil meta analisis diperoleh nilai regresi Egger's ( $\mathrm{p}=$ 0,568) dan korelasi rank Begg dan Mazumdar $(\mathrm{p}=0,327)$. Hasil ini tidak menunjukkan adanya bias publikasi (Tabel 4).

Table 4. Hasil rank correlation dan regression dari

\begin{tabular}{cccc}
\multicolumn{3}{c}{ funnel plot. } \\
\hline $\begin{array}{c}\text { Rank Correlation } \\
\text { Method }\end{array}$ & \multicolumn{2}{c}{ Regression Method } \\
\hline p-value & $\begin{array}{c}\text { Rank } \\
\text { Correlation }\end{array}$ & p-value & $\begin{array}{c}\text { Regression } \\
\text { coeficient }\end{array}$ \\
\hline 0,462 & 0,735 & 0,568 & 0,639 \\
\hline
\end{tabular}

Korelasi kadar HMGB1 dengan tingkat keparahan stenosis arteri koroner pada pasien SKA.

Pencarian literatur, ulasan, dan alasan untuk pengecualian studi dijelaskan pada gambar 3. Berdasarkan kata kunci yang 
relevan atau pencarian judul dalam pengambilan literatur penelitian, kami dapatkan 286 kutipan dalam pencarian awal kami. Setelah dilakukan tinjauan berdasarkan review judul dan abstraknya, kami dapatkan 16 judul yang relevan. Hasil akhir telusur artikel, didapatkan satu artikel yang memenuhi kriteria setelah penyaringan teks lengkap dan dimasukkan dalam penelitian ini (Huang et al.,2017) ${ }^{21}$, sehingga tidak dilakukan metaanalisis untuk keterkaitan kadar HMGB1 dengan stenosis arteri koroner.

Tabel 5. Keterkaitan kadar HMGB1 serum dengan stenosis arteri koroner.

\begin{tabular}{lccc}
\hline Studi & $\begin{array}{c}\text { Sample } \\
\text { size }\end{array}$ & $\mathrm{r}$ & $\mathrm{p}$ \\
\hline Huang et al., 2017 & 90 & 0,588 & 0,000 \\
\hline
\end{tabular}

Berdasarkan hasil tinjauan sistematis menunjukkan adanya korelasi antara kadar HMGB1 serum dengan stenosis arteri koroner, dengan kekuatan korelasi sedang. Selain itu didapatkan luaran penelitian lainnya yang bisa di tinjauan dari artikel tersebut menunjukkan adanya hubungan tingginya kadar HMGB1 dengan tipe SKA, rendahnya Left ventricular ejection fraction (LVEF), maupun berkorelasi positip sebagai prediktor kematian akibat kardiovaskuler ${ }^{21}$.

\section{DISKUSI}

Hasil tinjauan sistematis maupun meta analisis ini telah membuktikan adanya korelasi dan komparabilitas kadar asam urat dan HMGB1 serum dengan keparahan stenosis arteri koroner (skor Gensini). Sistem penilaian Gensini memberikan bobot pada kedekatan lesi di left main arteri koroner disamping tingkat stenosis yang mendapatkan skor maksimum. Skor akhir mencerminkan keparahan aterosklerosis arteri koroner karena meringkas efek kumulatif semua lesi.
Hasil tinjauan sistematis dan meta analisis korelasi kadar asam urat serum dengan tingkat keparahan stenosis arteri koroner pada SKA didapatkan adanya variasi antar penelitian. Variasi antar penelitian ini bisa disebabkan oleh berbagai faktor, antara lain terdapat perbedaan rentang usia partisipan dari masing-masing penelitian. Perbedaan jenis kelamin pria pada masing-masing penelitian juga terlihat pada penelitian Qureshi dkk (100\%), Duran dkk (82,5\%), Gaubert dkk (61,3\%), Pramanik dkk (61\%) dan Ma dkk $(50,5 \%)$. Masing-masing penelitian mencantumkan data karakteristik dasar faktor risiko kardiovaskuler termasuk hipertensi, diabetes, dislipidemia ${ }^{10,18,22}$, dan merokok $^{10,17,18,22}$. Namun pada penelitian lain mengeklusi diabetes melitus ${ }^{17,20}$ ataupun hipertensi ${ }^{17}$ dalam penelitiannya. Masingmasing penelitian juga menunjukkan perbedaan prosentase tipe klinis pasien SKA baik UAP NSTEMI dan STEMI, ${ }^{17,18,20,22}$ sedangkan satu penelitian lainnya hanya meneliti pasien SKA dengan tipe klinis UAP dan NSTEMI ${ }^{10}$. Perbedaan karakteristik partisipan yang meliputi faktor risiko kardiovaskuler termasuk usia, jenis kelamin pria, hipertensi, dislipidemia maupun diabetes melitus dan adanya perbedaan tipe klinis pasien SKA dari masing-masing studi, tentunya akan menyebabkan adanya heterogenitas dalam penelitian ini. Peningkatan kadar asam urat berhubungan dengan tipe klinis penyakit arteri koroner ${ }^{20}$ dan faktor risiko kardiovaskuler ${ }^{11}$. 


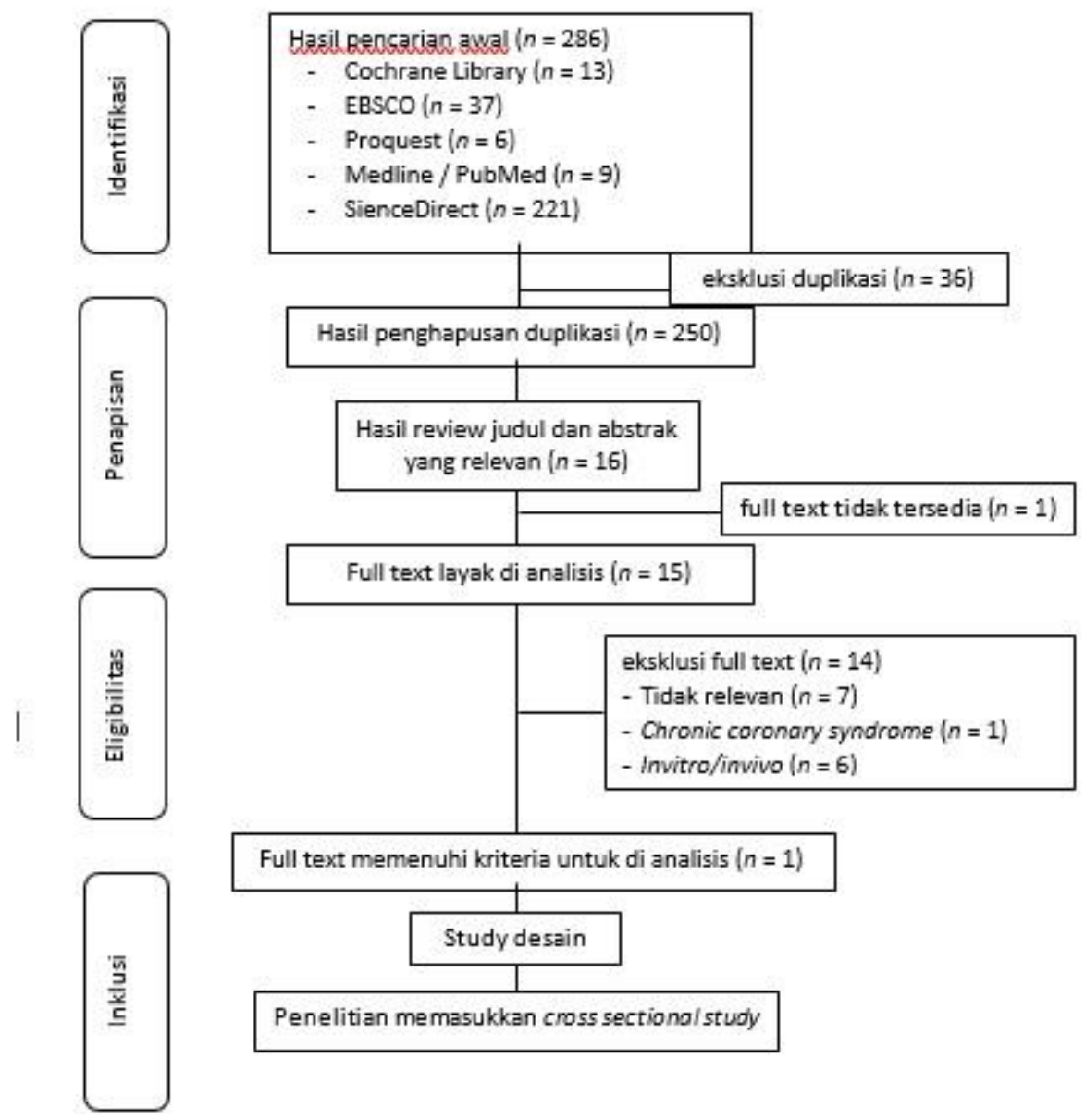

Gambar 3. Diagram alir korelasi HMGB1 serum dengan tingkat keparahan stenosis arteri koroner pada pasien SKA

Hasil tinjauan sistematis dan meta analisis yang kami lakukan didapatkan pada pasien-pasien SKA memiliki rata-rata kadar asam urat yang lebih tinggi. Hasil ini sejalan dengan hasil penelitian Fromonot dkk bahwa kadar asam urat serum lebih tinggi pada SKA dibandingkan $\mathrm{SKK}^{23}$. Peningkatan kadar asam urat serum dikaitkan dengan efek samping dan mortalitas pada pasien dengan infark miokard akut, serta dengan tingkat keparahan dan mortalitas penyakit arteri koroner akut. Selain itu, peningkatan kadar asam urat serum dikaitkan dengan peningkatan risiko kejadian klinis berikutnya dan mortalitas pada pasien dengan SKK.
Peningkatan kadar asam urat serum sedikit saja dari kisaran normal (hiperurisemia), mulai memiliki peningkatan yang signifikan dalam mortalitas jangka pendek pasien dengan STEMI dan mereka yang menjalani percutaneous coronary intervention (PCI) ${ }^{6}$. Penelitian Ma dkk melaporkan pening-katan kadar asam urat serum berhubungan dengan tipe klinis penyakit arteri koroner ${ }^{20}$. Hasil ini sejalan dengan penelitian Fromonot dkk yang melaporkan bahwa pasien dengan penyakit arteri koroner meningkatkan kadar asam urat serum dibandingkan dengan orang sehat ${ }^{23}$.

Korelasi asam urat serum dengan keparahan stenosis, dimungkinkan melalui proses patomekanisme adanya SKA 
menyebabkan iskemia dan nekrosis miokard akut akibat stenosis arteri koroner yang parah dan bahkan penyumbatan. Keadaan iskemik ini akan menginduksi terjadinya metabolisme anaerob, yang mengarah pada rendahnya produksi ATP dan kegagalan saluran pertukaran ion yang mengganggu aktivitas enzimatik dalam sitoplasma. Kerusakan mitokondria dan ketidakseimbangan elektrolit dalam keadaan reperfusi meningkatkan stres oksidatif melalui tiga sistem utama, yaitu nicotinamide adenine dinucleotide phosphate (NADPH) oxidase, nitric oxide synthase (NOS) dan xanthine oxidase ${ }^{11,24}$. Peningkatan sistem xanthine oksidase ini selanjutnya akan menginduksi produksi reactive oxygen species (ROS) dengan mengoksidasi hipoksantin menjadi xantin, selanjutnya xantin menjadi asam urat, yang pada akhirnya akan terjadi lonjakan metabolit purin dalam sirkulasi yang mengarah pada hiperurisemia. Peran hiperurisemia dalam patogenesis aterosklerosis pasien SKA dimungkinkan melalui jalur NF$\kappa \mathrm{B}$ yang memediasi gangguan endotelium dan disfungsi vaskular melalui pengurangan nitric oxide (NO) dan ekspresi sitokin pro-inflamasi. Keterkaitan antara NF- $\kappa \mathrm{B}$ yang teraktivasi, pengurangan NO, respons imun maladaptif, dan disfungsi vaskular memungkinkan pengembangan strategi terapi baru untuk perlindungan penyakit kardiovaskular ${ }^{11}$.

Hasil tinjauan sistematis ini menunjuk-kan adanya korelasi tingkat sedang antara kadar HMGB1 serum dengan tingkat keparah-an sklerosis arteri koroner pada pasien SKA. Hal ini dimungkinkan karena selama SKA terjadi cedera iskemia-reperfusi, HMGB1 yang berada di sirkulasi berasal dari kardio-miosit nekrotik dan sekresi aktif oleh kardiak hipoksia dan sel inflamasi. Ekspresi HMGB1 miokard meningkat segera setelah iskemia dan tetap tinggi beberapa hari setelah reperfusi. HMGB1 ekstraseluler sendiri atau bersama dengan TNF- $\alpha$ meningkatkan apoptosis kardiomiosit yang diinduksi hipoksia/reoksigenasi melalui aktivasi Jun $\mathrm{N}$ - terminal kinase (JNK) dan $\mathrm{NF}-\kappa \mathrm{B}$ melalui TLR2/4. ${ }^{25}$ HMGB1 ekstraseluler dapat menstimulasi sel endotel pembuluh darah atau sel otot polos untuk mengekspresikan dan/ atau mensekresikan molekul adhesi, sitokin, kemokin, aktivator plasminogen, zat vasoaktif, mediator lipid, dan matriks metaloprotein, serta Receptor for Advanced Glycation Endproducts (RAGE 5,15,26. RAGE bertanggung jawab langsung untuk aktivitas HMGB1 dalam pembentukan plak aterosklerotik. Stres oksidatif dan aktivasi NF- $\kappa \mathrm{B}$ terlibat dalam aterosklerosis yang dimediasi oleh HMGB1-RAGE ${ }^{5,15}$.

Selain itu tinjauan sistematis ini didapatkan adanya luaran penelitian lainnya yang menunjukkan adanya hubungan tingginya kadar HMGB1 dengan tipe SKA, rendahnya LVEF, maupun berkorelasi positip sebagai prediktor kematian akibat kardiovaskuler. ${ }^{21}$ Hasil tersebut bertentangan dengan hasil penelitian kohort prospektif yang dilakukan Rath et al pada 183 pasien PJK (baik SKA dan sindrom koroner kronis/SKK), yang didapatkan hasil bahwa tidak ada hubungan tingginya ekspresi HMGB1 di trombosit dengan SKA ataupun SKK ( $p=$ 0,220) dan jenis PJK (PJK stabil, UAP, NSTEMI dan STEMI; $p=0,779)$. Selain itu juga didapatkan tidak ada hubungan tingginya ekspresi HMGB1 di trombosit dengan LVEF $(\mathrm{p}=0,266)^{27}$

Hasil tinjauan sistematis ini memungkinkan bahwa pengukuran kadar HMGB1 serum, merupakan molekul yang secara substansial peningkatannya dapat digunakan untuk stratifikasi risiko dan faktor independen kematian akibat kardiovaskuler pada pasien dengan angina tidak stabil dan NSTEMI lebih awal $^{21,28}$. Ketika terjadi cedera iskemia miokard akut, konsentrasi HMGB1 serum yang tinggi dapat memperburuk kerusakan miokard pada tahap awal SKA, sementara itu konsentrasi HMGB1 serum memainkan peran aktif dalam perbaikan otot miokard pada tahap akhir iskemia miokard akut ${ }^{21}$. Diperlukan 
penelitian lebih lanjut berkaitan dengan waktu dan konsentrasi HMGB1 di mana penatalaksanaan paling tepat untuk memperkuat regenerasi pembuluh darah, memulihkan fungsi jantung, dan meningkatkan prognosis pasien PJK.

Hasil tinjauan sistematis dan meta analisis yang kami lakukan didapatkan koefisien korelasi kadar asam urat serum dan keparahan stenosis arteri koroner memiliki hubungan yang sedang dan asosiasi kedua variabel adalah signifikan. Besarnya angka koefisien determinasi $\left(\mathrm{R}^{2}\right)$ adalah 0,300 atau sama dengan $30 \%$. Angka ini berarti bahwa variabel kadar asam urat serum secara simultan berpengaruh terhadap variabel keparahan stenosis arteri koroner sebesar $30 \%$, sedangkan sisanya $70 \%$ dipengaruhi oleh variabel lain yang tidak diteliti. Disamping faktor-faktor risiko aterosklerosis lainnya baik yang bisa dimodifikasi (seperti dislipidemi, merokok, Diabetes Mellitus/ resistensi insulin, hipertensi, penyakit ginjal kronik, sindrom metabolik, inflamasi sistemik) maupun yang tidak dapat dimodifikasi seperti usia, keturunan dan jenis kelamin (laki-laki) $^{11,29}$. Kadar asam urat serum dapat dipertimbangkan sebagai faktor risiko aterosklerosis. Beberapa penelitian mengungkapkan bahwa peningkatan kadar asam urat serum hanya dianggap sebagai respons adaptasi untuk mencoba mencegah aterosklerosis, karena sifat anti-oksidan dari asam urat $^{6,30}$.

Penelitian ini masih ada keterbatasannya, yaitu: (i) tinjauan sistematis terbatas hanya pada artikel berbahasa Inggris sesuai kriteria peneliti, sehingga memungkinkan akan terjadi perbedaan estimasi effect size korelasi apabila memasukkan studi-studi yang berbahasa non-Inggris, (ii) peneliti hanya mengandalkan mesin pencari elektronik untuk mencari jenis penelitian yang sesuai dengan kriteria yang telah ditentukan. Kemungkinan masih ada beberapa penelitian yang sesuai dengan kriteria yang telah kita tentukan terlewatkan dari pencarian dan tidak diiukutsertakan dalam meta analisis ini.

\section{KESIMPULAN}

Berdasarkan hasil penelitian ini, dapat disimpulkan bahwa ada korelasi antara kadar asam urat dan HMGB1 serum dengan tingkat keparahan stenosis arteri koroner pada SKA. Perlu dipertimbangkan untuk memasukkan penggunaan obat penurun asam urat dalam Panduan Praktik Klinik SKA. Perlu dilakukan penelitian lebih lanjut peran HMGB1 serum dalam patogenesis aterosklerosis pasien SKA.

\section{DAFTAR PUSTAKA}

1. Timmis A, Townsend N, Gale CP, Torbica A, Lettino M, Petersen SE, et al. European society of cardiology: Cardiovascular disease statistics 2019. Eur Heart J. 2020;41(1):1285.

2. Chan MY, Du X, Eccleston D, Ma C, Mohanan PP, Ogita M, et al. Acute coronary syndrome in the Asia-Pacific region. Int $\mathrm{J}$ Cardiol . 2016;202:861-9.

3. Anderson JL, Morrow DA. Acute Myocardial Infarction. N Engl J Med. 2017;376(21):2053-64.

4. Chen Q, Wang ZY, Chen LY, Hu HY. Roles of High Mobility Group Box 1 in Cardiovascular Calcification. Cellular Physiology and Biochemistry. 2017;42(2):427-40.

5. Pellegrini L, Foglio E, Pontemezzo E, Germani A, Russo MA, Limana F. HMGB1 and repair: focus on the heart. Pharmacol Ther. 2019;196:160-82.

6. Larsen TR, Gerke O, Diederichsen ACP, Lambrechtsen J, Steffensen FH, Sand NP, et al. The association between uric acid levels and different clinical manifestations of coronary artery disease. Coron Artery Dis. 2018;29(3):194-203.

7. Casiglia E, Tikhonoff V, Virdis A, Masi S, Barbagallo CM, Bombelli M, et al. Serum uric acid and fatal myocardial infarction: Detection of prognostic cut-off values: The URRAH (Uric Acid Right for Heart Health) study. J Hypertens. 2020;38(3):412-9.

8. Culleton BF, Larson MG, Kannel WB, Levy D. Serum uric acid and risk for cardiovascular disease and death: The Framingham Heart Study. Curr Hypertens Rep. 2000;2(1):5-6. 
9. Zalawadiya SK, Veeranna V, MallikethiReddy S, Bavishi C, Lunagaria A, Kottam A, et al. Uric acid and cardiovascular disease risk reclassification: Findings from NHANES III. Eur J Prev Cardiol. 2015;22(4):513-8.

10. Gaubert M, Marlinge M, Alessandrini M, Laine M, Bonello L, Fromonot J, et al. Uric acid levels are associated with endothelial dysfunction and severity of coronary atherosclerosis during a first episode of acute coronary syndrome. Purinergic Signal. 2018;14(2):191-9.

11. Ndrepepa G. Uric acid and cardiovascular disease. Clin Chim Acta. 2018;484:150-63.

12. Akanda M, Choudhury K, Ali M, Naher S, Islam A, Ali M. Serum Uric Acid and Its Association with Coronary Artery Disease. Cardiovasc J. 2012;5(1):12-7.

13. Ekici B, Kutuk U, Alhan A, Tore HF. The relationship between serum uric acid levels and angiographic severity of coronary heart disease. Kardiol Pol. 2015;73(7):533-8.

14. Hu X, Jiang H, Bai Q, Zhou X, Xu C, Lu Z, et al. Increased serum HMGB1 is related to the severity of coronary artery stenosis. Clin Chim Acta . 2009;406(1-2):139-42.

15. Kang R, Chen R, Zhang Q, Hou W, Wu S, Cao L, et al. HMGB1 in Health and Disease. Mol Asp Med. 2014;1-116.

16. Cai W, Duan XM, Liu Y, Yu J, Tang YL, Liu ZL, et al. Uric Acid Induces Endothelial Dysfunction by Activating the HMGB1/RAGE Signaling Pathway. Biomed Res Int. 2017; 2017:4391920.

17. Duran M, Kalay N, Akpek M, Orscelik O, Elcik D, Ocak A, et al. High levels of serum uric acid predict severity of coronary artery disease in patients with acute coronary syndrome. Angiology. 2012;63(6):448-52.

18. Pramanik S, Mondal K, Dey AK, Mandal PK, Das SK, Momin TW, et al. A study of angiographic severity in patients with coronary artery disease and hyperuricemia. Asian J Med Sci. 2015;7(2):1-4.

19. Qureshi AE, Hameed S, Noeman A. Relationship of serum uric acid level and angiographic severity of coronary artery disease in male patients with acute coronary syndrome. Pakistan J Med Sci. 2013;29(5):1137-42.

20. Ma QQ, Yang XJ, Yang NQ, Liu L, Li XD, Zhu K, et al. Study on the levels of uric acid and high-sensitivity C-reactive protein in ACS patients and their relationships with the extent of the coronary artery lesion. Eur Rev Med Pharmacol Sci. 2016;20(20):4294-8.

21. Huang J, Chen J, Ren Y, Bai CC, Zhang YB, Du GS. Correlation between high mobility group box 1 protein, tumor necrosis factor- $\alpha$, and acute coronary syndrome. Biomed Res. 2017;28(9):3798-803.

22. Qureshi AE, Hameed S, Noeman A. Relationship of serum uric acid level and angiographic severity of coronary artery disease in male patients with acute coronary syndrome. Pakistan J Med Sci. 2013;29(5):1137-41.

23. Fromonot J, Deharo P, Bruzzese L, Cuisset T, Quilici J, Bonatti S, et al. Adenosine plasma level correlates with homocysteine and uric acid concentrations in patients with coronary artery disease. Can J Physiol Pharmacol. 2016;Mar;94.(3):272-7.

24. Zhen H, Gui F. The role of hyperuricemia on vascular endothelium dysfunction. Biomed Reports. 2017;7(4):325-30.

25. Raucci A, Di Maggio S, Scavello F, D'Ambrosio A, Bianchi ME, Capogrossi MC. The Janus face of HMGB1 in heart disease: a necessary update. Cell Mol Life Sci. 2019;76(2):211-29.

26. Martinotti S, Patrone M, Ranzato E. Emerging roles for HMGB1 protein in immunity, inflammation, and cancer. ImmunoTargets Ther. 2015;4:101-9.

27. Rath D, Geisler T, Gawaz M, Vogel S. HMGB1 Expression Level in Circulating Platelets is not Significantly Associated with Outcomes in Symptomatic Coronary Artery Disease. Cell Physiol Biochem. 2017;43(4):1627-33.

28. Hashimoto T, Ishii J, Kitagawa F, Yamada S, Hattori K, Okumura M, et al. Circulating high-mobility group box 1 and cardiovascular mortality in unstable angina and non-STsegment elevation myocardial infarction. Atherosclerosis . 2012;221(2):490-5.

29. Rafieian-kopaei M, Setorki M, Doudi M, Baradaran A, Nasri H. Atherosclerosis : Process,Indicators, Risk Factors and Background. Int J Prev Med. 2018;5(8):92746

30. Sun Y, Yu X, Zhi Y, Geng S, Li H, Liu T, et al. A cross-sectional analysis of the relationship between uric acid and coronary atherosclerosis in patients with suspected coronary artery disease in China. BMC Cardiovasc Disord. 2014;14:101. 